\title{
Proceedings of the Annual Meeting of the Georgia Association of Mathematics Teacher Educators
}

\section{Proceedings of the Fourth Annual Meeting of the Georgia Association of Mathematics Teacher Educators Introductory Texts}

DOI

10.20429/gamte.2010.040101

Follow this and additional works at: https://digitalcommons.georgiasouthern.edu/gamte-proceedings

Part of the Mathematics Commons, and the Teacher Education and Professional Development Commons

\section{Recommended Citation}

(2010) "Proceedings of the Fourth Annual Meeting of the Georgia Association of Mathematics Teacher Educators Introductory Texts," Proceedings of the Annual Meeting of the Georgia Association of Mathematics Teacher Educators: Vol. 4 : Iss. 1 , Article 1.

DOI: $10.20429 /$ gamte.2010.040101

Available at: https://digitalcommons.georgiasouthern.edu/gamte-proceedings/vol4/iss1/1

This article is brought to you for free and open access by the Journals at Digital Commons@Georgia Southern. It has been accepted for inclusion in Proceedings of the Annual Meeting of the Georgia Association of Mathematics Teacher Educators by an authorized administrator of Digital Commons@Georgia Southern. For more information, please contact digitalcommons@georgiasouthern.edu. 
Proceedings of the Fourth Annual Meeting of the Georgia Association of Mathematics Teacher Educators

October 13, 2010 Rock Eagle, Georgia 


\title{
Georgia Association of Mathematics Teacher Educators (GAMTE)
}

\author{
GAMTE 2010 Officers \\ President \\ President Elect \\ Secretary \\ Treasurer \\ Member-at-Large \\ Member-at-Large \\ Member-at-Large \\ Cindy Henning, Columbus State University \\ Sharon Taylor, Georgia Southern University \\ Dianna Spence, North Georgia College \& State University \\ Nikita Patterson, Kennesaw State University \\ Don Brown, Macon State University \\ Deborah Gober, Columbus State University \\ Mary Garner, Kennesaw State University
}

GAMTE 2010 Conference Committee

Sharon Taylor (chair), Georgia Southern University

Don Brown, Macon State University

Joy Black, University of West Georgia

\section{GAMTE 2010 Proceedings Committee}

Deborah Gober (chair), Columbus State University

Don Brown, Macon State University

Linda Crawford, Augusta State University

Jill Drake, University of West Georgia

Mary Garner, Kennesaw State University

Cindy Henning, Columbus State University

Ellice Martin, Valdosta State University

\section{Purposes and Goals of GAMTE}

The purpose of GAMTE is to encourage and facilitate the improvement of mathematics teacher education across the state of Georgia. The goals of the organization are to: facilitate communication and collaboration among mathematics teacher educators between and within all educational levels; coordinate activities and work collaboratively with other associations, organizations, and governmental (national, state, and local) units to strengthen the mathematical, pedagogical, and clinical preparation of mathematics teachers at all levels (P-college); facilitate collaboration among mathematics teacher educators who are members of different academic units, such as departments of mathematics and departments of education; promote leadership among mathematics teacher educators in the broader mathematics education community; encourage research related to mathematics teacher education, especially which identifies factors that contribute to improving the preparation and professional development of mathematics teachers at all levels; encourage and organize programs and meetings focusing in issues related to the preparation and professional development of mathematics teachers; and foster the incorporation of appropriate technology into teacher education programs and professional development opportunities in mathematics at all levels ( $\mathrm{P}$ - college). 
Table of

Contents

Page Number

\section{Research}

Investigating Mathematical Literacy through Teacher Language ..........................................4 Alyson Lischka, Kennesaw State University

Collaborating to Meet the Standards: Implications for Professional Development 12

Erik D. Jacobson and Laura M. Singletary, University of Georgia

\section{Research into Practice}

Extending K-8 Mathematics Concepts in Alternate Bases

Dianna J. Spence, North Georgia College \& State University

\section{Teaching}

Basic Skills Testing in Math 2008

Susie M. Lanier, Sharon E. Taylor, Donna B. Saye, Georgia Southern

University

Embracing the Vision: Our Work with Teachers Implementing GPS 34

Sarah Ledford, Wendy B. Sanchez, Marian Fox, Kennesaw State University 